\title{
ISU TERORISME DAN RESPONS AKTIVIS MUDA ACEH
}

\author{
M. Hasbi Amiruddin \\ UIN Ar-Raniry Darussalam Banda Aceh \\ e-mail: hasbi_amiruddin@yahoo.com
}

\begin{abstract}
This article wants to examine the extent of radical thought in the minds of the younger generation pervasive in Aceh. With the new Aceh conditions experienced several years of post-conflict situation safe again struck by discovered a number of terrorists who make Jalin mountains forest, Aceh Besar, as a military training ground. Also found are also a number of books that have a narrative that can bring inspiration radicalism and terrorism acts. The results of in-depth interviews of young activists in Aceh, can be explained that the concept of terrorism models struggle can not be accepted by young activists in the city of Banda Aceh. They have to understand the teachings of Islam that is relatively comprehensive and proportional. But their ideals in order to uphold Islamic shariah in Aceh is a necessity.

Artikel ini ingin melihat sejauhmana pemikiran radikal merasuk dalam pikiran generasi muda di Aceh. Dengan kondisi Aceh yang baru beberapa tahun mengalami situasi aman pasca terjadi konflik kembali dikejutkan dengan ditemukan sejumlah teroris yang menjadikan hutan pegunungan Jalin, Aceh Besar, sebagai medan latihan militer. Selain itu ditemukan juga sejumlah buku-buku yang memiliki narasi yang dapat memunculkan inspirasi tindakan radikalisme dan terorisme. Hasil wawancara mendalam terhadap para aktivis muda Aceh, dapat dijelaskan bahwa konsep perjuangan model terorisme tidak dapat diterima oleh aktivis muda di Kota Banda Aceh. Mereka telah memahami ajaran Islam yang relatif komprehensif dan proporsional. Namun cita-cita mereka agar tegaknya syariat Islam di Aceh adalah suatu keniscayaan.
\end{abstract}

Keywords: terorisme, radikalisme, aktivis muda Aceh 


\section{A. Pendahuluan}

Sejak peristiwa bom Bali I sampai sekarang ini, Polri telah berhasil menangkap terduga teroris mendekati 600 orang. Hingga 11 Januari 2013 Polri sudah berhasil menangkap 583 orang, tewas saat disergap 55 orang dan divonis bersalah sebanyak 388 orang. Di sisi lain korban tewas aksi teroris sebanyak 298 orang dan korban luka-luka 838 orang. ${ }^{1}$ Namun keberhasilan Polri tidak mengindikasikan berakhirnya gerakan terorisme di Indonesia. Secara episodik dan pasti, serangan terorisme terus muncul terhadap objek tertentu, bahkan sudah sampai pada sistem bom bunuh diri seperti yang terjadi di Hotel JW Mariott dan Riz Carlton pada 17 Juli 2009.2 Terakhir disinyalir teroris telah berani menyerang polisi yang selama ini diandalkan sebagai pengaman negara termasuk dari gangguan para teroris. ${ }^{3}$

Aceh yang baru beberapa tahun hidup dalam situasi relatif aman, setelah terjadi perjanjian damai Helsinki antara Gerakan Aceh Merdeka (GAM) dengan Pemerintah RI, pada tahun 2005 dikejutkan dengan sebuah peristiwa tertangkapnya sejumlah orang yang diduga teroris di Aceh pada Februari 2010. Hampir semua orang Aceh tidak percaya akan peristiwa tersebut. Di mana-mana terjadi diskusi, mereka menganggap itu merupakan rekayasa pihak tertentu untuk menjelek-jelekkan Aceh. Apalagi beberapa media elektronik sering menyebutkan kata-kata teroris Aceh, yang ternyata setelah dipaparkan namanama yang terlibat nama-nama mereka memang tidak bertradisi Aceh. Bahkan tokoh yang disebut-sebut salah satu pimpinan mereka dengan nama tradisi Aceh, Abu Rimba, ternyata tidak bisa berbahasa Aceh. Tetapi bagaimanapun ternyata sejumlah orang yang divonis sebagai terpidana teroris kemudian mengaku sendiri sebagai orang Aceh. Bahkan mereka merasa kecewa karena setelah divonis bersalah di pengadilan Jakarta tidak ditahan di Aceh, tetapi dikirim ke LP Tanjung Gusta, Medan, Sumatera Utara.

Demikian juga diam-diam di Aceh beredar buku-buku yang memiliki narasi yang dapat memunculkan inspirasi tindakan radikalisme dan bahkan terorisme. Buku-buku tersebut ditulis berseri, sangat mungkin juga dikirim mengikuti seri

\footnotetext{
1Mansyur Faqih, dkk, “Ketika Pemberantasan Terorisme Meresahkan," Republika, 11 Januari 2013. 2Munajat, "Memahami Gerakan Terorisme: Mungkinkah Berakhir?” Republika, 10 Agustus 2009. 2013.

3Irfan Fitrat dan Dyah Ratna Novia, "Polisi Curigai Keterlibatan Teroris," Republika, 19 Agustus,

4Bah, “Terpidana Teroris Kecewa Tidak Ditahan di Aceh," Serambi Indonesia, 20 Desember 2011.
} 
penerbitan tersebut. Itu artinya Aceh dapat menjadi objek wilayah yang memproduksi teroris di masa yang akan datang. Berdasarkan hal tersebut penulis tertarik membuat suatu penelitian untuk melihat bagaimana respons generasi muda di Aceh.

Untuk tahap pertama akan difokuskan pada bagaimana pandangan aktivis muda di kota Banda Aceh saja. Yang dimaksud aktivis muda di sini adalah pimpinan atau mantan pimpinan organisasi yang digolongkan sebagai generasi muda seperti PII, HMI, KAMMI, Iskada, LDK, Remaja Mesjid, Khatib muda, Pengurus Mesjid (BKM) muda, Thaliban, IMM, Rohis, dosen muda yang aktif sebagai mentor pengajian agama Islam di kampus. Umur responden berkisar 2236 tahun. Signifikasinya memilih lokasi responden Banda Aceh adalah biasanya Banda Aceh menjadi sumber gerakan-gerakan yang berbasis ideologi. Hampir semua organisasi pemuda memiliki markas pusatnya di Banda Aceh. Demikian juga Banda Aceh merupakan kota para orang terpelajar, karena di Banda Aceh terdapat 6 Universitas negeri dan swasta dan juga sejumlah Sekolah Tinggi lainnya. Aktivis-aktivis biasanya berasal dari para mahasiswa atau alumni suatu universitas. Organisasi santri sendiri kendatipun kebanyakan pesantren (Aceh: Dayah) terdapat di desa-desa di seluruh Aceh, tetapi juga memiliki markas pusatnya di Banda Aceh. Jadi jika suatu kegiatan akan berlangsung di daerahdaerah tertentu biasanya inspirasi awalnya ada di Banda Aceh. Karena itu pula penelitian ini menjadikan para aktivis muda sebagai responden dengan wawancara mendalam tentang tanggapannya terhadap isu terorisme.

\section{B. Pandangan dan Respons terhadap Terorisme di Aceh}

\section{Pandangan Majelis Permusyawaratan Ulama Aceh}

Terorisme dalam Kamus Besar Bahasa Indonesia diawali dengan penjelasan dari kata teror yang maknanya adalah usaha menciptakan ketakutan, kengerian dan kekejaman oleh seseorang atau golongan. Teroris adalah orang yang menggunakan kekerasan untuk menimbulkan rasa takut, biasanya untuk kepentingan politik. Terorisme adalah penggunaan kekerasan untuk menimbulkan ketakutan, usaha mencapai suatu tujuan (terutama untuk politik) melalui praktek-praktek teror.5 Definisi tentang terorisme yang agak rinci diberikan oleh Marianne

5Tim Penyusun Kamus, Kamus Besar Bahasa Indonesia, (Jakarta: Balai Pustaka, 1999), h. 1049. 
Katoppo yaitu pemaksaan kehendak suatu kelompok atau golongan dengan tindakan-tindakan teror: pembunuhan, pembantaian, penculikan, penyanderaan. Pembuatan pernyataan "agar dunia tahu siapa kami" dengan tindakan-tindakan biadab dan tidak manusiawi yang dilakukan tiba-tiba, tidak terduga, pada sasaran-sasaran yang tidak disangka-sangka, yang tidak bersalah. ${ }^{6}$

Berdasarkan terjadinya peristiwa penangkapan sejumlah orang terduga teroris yang sedang mengadakan pelatihan militer di Pegunungan Jalin, ${ }^{7}$ Jantho Aceh Besar, Majelis Permusyawaratan Ulama di Aceh telah mengadakan rapat kerja untuk menetapkan fatwa mengenai terorisme. Setelah bersidang satu hari penuh pada tanggal 30 Juni 2010, Majelis Permusyawaratan Ulama (MPU) Aceh mengeluarkan fatwa bahwa melakukan teror adalah haram dan perbuatannya termasuk dosa besar. Yang dimaksud dengan terorisme menurut MPU Aceh adalah paham atau ideologi yang membenarkan pengrusakan, menimbulkan ketakutan dalam masyarakat, dilakukan dengan alasan yang tidak benar (bighairi haq) dan dengan tujuan yang bertentangan dengan syariat Islam. ${ }^{8}$

\section{Respons Aktivis Muda Aceh}

Ada beberapa terma yang dapat menjelaskan bagaimana sikap aktivis muda Aceh terhadap tindakan terorisme, seperti kata jihad, perang, radikal, teroris. Selain itu juga terma ideologi jahiliyyah (syirik) yaitu demokrasi, nasionalis, liberalis dan Pancasila. Beberapa istilah ini terdapat dalam narasi Tazkiroh yang ditulis oleh Ustaz Abu Bakar Ba'asyir. ${ }^{9}$

Jika terma teroris seperti yang didefinisikan di atas, yaitu pembunuhan, pembantaian, penculikan, penyanderaan dengan tindakan-tindakan biadab dan tidak manusiawi yang dilakukan tiba-tiba, tidak terduga, pada sasaran-sasaran yang tidak disangka-sangka, terhadap orang-orang tidak bersalah, apakah dalam bentuk pemboman atau dalam bentuk lain, semua aktivis muda Aceh tidak setuju terhadap tindakan tersebut. Alasan mereka karena agama Islam tidak membenarkan tindakan yang merusakkan dan mengorbankan orang tak berdosa.

\footnotetext{
6Marienne Katoppo, Teroris Serang Islam, (Bandung: Pustaka Hidayah, 2000), h. 30.

7Jalin adalah nama sebuah desa terpencil di sebuah pegunungan dalam wilayah Kabupaten Aceh Besar, kira-kira $20 \mathrm{~km}$ dari jalan negara Banda Aceh-Medan atau $100 \mathrm{~km}$ dari kota Banda Aceh.

${ }^{8}$ Majelis Permusyawaratan Ulama Aceh, Fatwa MPU No. 02 Tahun 2010 mengenai Terorisme.

${ }^{9}$ Penulisan nama Ustaz Abu Bakar Ba'asyir berdasarkan tulisan yang terdapat di sampul buku tersebut, tetapi kebanyakan aktivis muda di Banda Aceh belum tahu tentang buku tersebut sehingga mereka tidak sepenuhnya percaya bahwa buku itu ditulis oleh Ustaz Abu Bakar Ba'asyir.
} 
Dalam situasi perang saja Islam tidak membenarkan membunuh orang tak bersalah, binatang dan pohon-pohonan saja tidak boleh dikorbankan. Sehingga ada di antara mereka yang memberi pernyataan, kalau ada aktivitas seperti itu walaupun dilakukan oleh seorang Muslim, tidak boleh dikaitkan dengan Islam. Itu adalah tindakan oknum dan pasti ada tujuan tertentu. Banyak juga yang mencurigai bahwa tindakan itu bukan berasal dari aktivis yang benar-benar mengerti ajaran Islam.

Jika dihubungkan dengan pemboman seperti yang pernah terjadi di Bali atau di tempat lain dianggap sebagai kegiatan teroris di Indonesia, menurut mereka adalah hasil rekayasa orang lain dengan tujuan menjelekkan Islam. Jikapun benar Amrozi terlibat, hal tersebut terjadi hanya karena kekecewaan dan keputusasaan terhadap situasi lingkungannya yang kemudian dimanfaatkan oleh orang lain. Bahkan ada yang memberi argumen bahwa bom Bali sebenarnya bukan bom yang dibuat Amrozi. Tidak mungkin Amrozi yang merupakan alumni pesantren tingkat tidak terlalu tinggi dan bukan ahli dalam bidang teknologi dapat membuat bom sedahsyat itu. Berdasarkan hasil bacaannya, salah seorang aktivis mengatakan bahwa dalam peristiwa bom Bali, ada bom lain di balik bom Amrozi yang berkekuatan mikro nuklir. Bom semacam ini tidak mungkin diracik oleh Amrozi.

Mereka berbeda pendapat ketika dihubungkan dengan Bom WTC yang terjadi di Amerika. Sebagian mereka menganggap itu adalah rekayasa Amerika sendiri sebagai pembenaran mencari Osama Bin Laden, yang pada akhirnya bertujuan untuk melumpuhkan politik Islam. Rata-rata aktivis muda Aceh tahu mengenai latar belakang hidup Osama Bin Laden yang sebelumnya adalah mitra Amerika ketika menghancurkan komunis di Afganistan. Tetapi ketika Osama bin Laden tidak sejalan lagi dengan Amerika, maka dia harus dikorbankan. Sebagian mereka berpendapat kalaupun benar peristiwa WTC adalah hasil inspirasi dari Osama Bin Laden, mereka setuju saja, karena mereka telah muak dengan hegemoni Barat dan sikap bermuka dua (double standard) negeri Paman Sam itu. Aktivis muda Aceh juga melihat kelakuan Amerika dan kebanyakan negaranegara Barat selama ini telah menghancurkan Islam dan umatnya. Hampir semua aktivis muda Aceh bersimpati pada Osama Bin Laden, apalagi setelah mendengar cara-cara Amerika memperlakukan mayat Osama Bin Laden yang tidak menghormati tradisi Islam.

Selain bersikap simpati pada Osama Bin Laden dan perjuangannya, aktivis muda Aceh juga berbeda pendapat mengenai persoalan perjuangan umat Islam 
di Afganistan dan Palestina. Kendatipun mereka tidak setuju dengan tindakan teroris, tetapi mereka memahami apa yang dilakukan oleh umat Islam di Afganistan dan Palestina. Menurut mereka, itu adalah kondisi keterpaksaan karena mereka terjepit oleh kekuatan raksasa. Tetapi tindakan seperti itu tidak cocok untuk Indonesia. Demikian juga sebaliknya, strategi perjuangan umat Islam di Indonesia mungkin tidak cocok diterapkan di Afganistan atau Palestina.

Tentang tindakan radikalisme, baik dalam rangka pemberantasan kemaksiatan maupun tindakan penyelamatan akidah umat, baik yang disebabkan oleh ada aliran sesat maupun ada usaha memaksakan agama lain, pada dasarnya aktivis muda Aceh tidak setuju. Menurut mereka semua itu dapat dimusyawarahkan dan di negeri kita ada aparatur negara yang memiliki otoritas untuk mengatur ini. Tetapi ketika ada kelompok tertentu yang tidak mematuhi ketentuan yang ada dan kemudian pemerintah juga tidak bertindak, itu wajar kalau muncul tindakan radikal. Karena itu menyangkut keselamatan generasi Islam. Jika dibiarkan mereka berlaku seenaknya, nantinya anak-anak Aceh tidak akan terselamatkan, apalagi kalau yang terlibat itu adalah keluarganya. Masyarakat Aceh akan sangat merasa malu jika ada keluarganya yang memeluk agama lain karena hal tersebut merupakan martabat keluarga dan bangsa. ${ }^{10}$

Pada tahun 2012 sebuah organisasi aktivis muda meneliti aktivitas gereja di Banda Aceh. Ditemukan data sebanyak 15 gereja ternyata ilegal. Kaum nonMuslim meresmikan bahwa bangunan yang digunakan tersebut sebagai kantor, ternyata pada prakteknya bangunan tersebut difungsikan sebagai gereja. Lalu para aktivis melaporkan ini kepada Walikota untuk diluruskan. Walikota memanggil para pendeta dan mengadakan musyawarah. Mereka membuat perjanjian akan mematuhi ketentuan daerah. Ada pendeta yang berkeras tidak mau mengikuti perjanjian, lalu Walikota menyatakan, kalau mereka tidak mau mengikuti aturan jika terjadi sesuatu pemerintah tidak bertanggung jawab. Aktivis muda itupun memberi pernyataan, kalau masih terjadi penyelewengan dari aturan dan kalau pemerintah tidak bertindak, kami akan bertindak. Tetapi secara umum kalau terjadi tindakan radikal selama ini aktivis muda Aceh menganggap ada tangan lain yang terlibat di belakangnya dengan tujuan agar umat Islam terus terpecah-pecah dan tidak pernah bersatu.

\footnotetext{
${ }^{10}$ Sebagai catatan, masih banyak masyarakat Aceh walaupun mereka sudah bersatu menjadi bangsa Indonesia, tetapi mereka masih merasa sebagai bangsa Aceh sama dengan bangsa Islam.
} 
Terma "jihad" dan "perang" dalam pandangan aktivis muda Aceh ada ketentuannya, karena dalam Islam kedua masalah tersebut merupakan ajaran resmi dan dibolehkan. Jihad, makna sesungguhnya adalah bersungguh-sungguh dalam berusaha untuk izzul Islam. Jihad juga bisa dalam bentuk harta dan pikiran. Tetapi kalau jalan lain sudah tertutup dan diplomasi tidak jalan lagi, baru perang. Hanya saja perang itu harus jelas, perang dengan siapa. Perang dalam konsep Islam juga harus jelas strukturnya. Ada pimpinan, ada angkatan perang dan harus jelas wilayah perang. Bom bunuh diri tidak masuk dalam strategi berperang dalam Islam. Apalagi jika bom tersebut membunuh atau melukai orang yang tak bersalah yang sebagian korbannya malah orang Islam. Islam melarang membunuh manusia, siapa saja, apalagi sesama Islam. Binatang dan tumbuh-tumbuhan saja tidak dibenarkan untuk dikorbankan walaupun dalam keadaan perang. Namun mempertahankan harta atau mempertahankan diri termasuk perangyang diwajibkan.

Tidak ada aktivis muda Aceh yang setuju pada terma "ideologi jahiliyyah/ syirik" yang dilabelkan pada negara Indonesia, karena menggunakan demokrasi, nasionalisme dan Pancasila. Mereka sudah menerima konsep negara bangsa yang berasaskan Pancasila. Sebagian mereka malah menganggap negara Indonesia yang berdasarkan Pancasila ini sudah islami. Pendapat yang paling ekstrim hanya mengatakan belum islami, tetapi tetap dapat menerima kehadiran negara ini walaupun untuk sementara. Mengenai negara berbentuk khiläfah, mereka tidak menolak seratus persen, karena ada kemungkinan di suatu waktu negara-negara yang mayoritas umat Islam atau negara-negara Islam dapat bersatu lagi, paling tidak semacam Uni Eropa atau OKI yang serius.

Yang berpendapat bahwa negara Indonesia sudah islami menurut mereka karena Pancasila yang menjadi dasar negara adalah percikan dari ajaran Islam, mulai dari sila pertama Ketuhanan Yang Maha Esa sampai sila kelima Kemanusiaan yang Adil dan Beradab. Apalagi bila dilihat pada preambulenya pada alinea ketiga disebut dengan jelas bahwa kemerdekaan Indonesia adalah berkat rahmat Allah Yang Maha Kuasa. Tentu konsep Allah tidak ada dalam agama lain kecuali dalam Islam. Demikian juga ketentuan-ketentuan lainnya secara umum tercermin berdasarkan dari ajaran Islam. Kalaupun masih terdapat hal-hal yang tidak sesuai dengan ketentuan syariat Islam mungkin peninggalan masa lalu dan itu adalah tugas generasi sekarang untuk menyelaraskannya.

Yang berpendapat bahwa negara Indonesia belum islami, tetapi dapat menerimanya adalah karena secara umum aturan-aturan negara di Indonesia 
tidak banyak yang bertentangan dengan syariat Islam. Demikian juga tindak tanduk dari para pejabat baik tingkat elit maupun bawahan belum dapat menjadi contoh sebagai uswah hasanah. Tindak tanduk dari pimpinan-pimpinan negara ada hubungannya dengan aturan yang ada di Indonesia. Karena itu, hal tersebut memerlukan perbaikan. Jalan yang lebih mudah ditempuh adalah melalui pendidikan. Pendidikan yang baik nanti akan membentuk pandangan (weltanschauung) masyarakat yang mengarah kepada kebaikan. Barangkali ketika masyarakat telah memiliki visi yang sejalan dengan ajaran agama ketika itu akan tercipta negara yang islami.

Terma "demokrasi" dalam pandangan aktivis muda Aceh tidak jahiliyyah atau syirik. Menurut mereka kendatipun terma itu datangnya dari Barat tetapi inti dari ajaran demokrasi sama dengan terma musyawarah dalam Islam yaitu setiap sesuatu masalah yang akan dilakukan haruslah disepakati bersama. Kalau ada perbedaan di sana sini itu bukan karena perbedaan inti dari ajaran masingmasing terma tersebut, tetapi lebih kepada perbedaan yang dipengaruhi oleh tingkat pendidikan masyarakat, pengaruh geografi, tradisi dan agama yang dianut oleh masyarakat tertentu.

Kalau ada yang berpendapat bahwa antara demokrasi dan musyawarah adalah berbeda sebenarnya juga tidak semua benar. Mengikuti tulisan di Tazkiroh yang selama ini menjadi sumber inspirasi para mujahid yang ingin memperjuangkan tegaknya hukum Allah bahwa musyawarah adalah dilakukan oleh para ulama dan akan diambil pendapat yang terbaik yang sejalan dengan ajaran Islam. Sebenarnya demokrasi pun akan seperti itu jika umat yang bermusyawarah sudah memahami Islam secara dalam. Tidak mungkin seorang Muslim yang benar-benar memahami Islam dan taat pada ajaran agama akan mengambil keputusan yang bertentangan dengan agama. Karena itu tugas kita bukan memerangi orang Islam yang belum memahami Islam secara mendalam, tetapi tugas kita dan tugas negara adalah memberi pencerahan kepada mereka sehingga mereka akan sampai menjadi orang-orang yang memahami agama secara mendalam dan mengamalkan seluruh ajaran itu dalam semua aspek hidupnya.

\section{Pencegahan Reproduksi Terorisme di Aceh}

Pertama, dari jawaban-jawaban yang diberikan oleh para aktivis muda Aceh, nampaknya jawaban itu secara murni berangkat dari pikiran mereka ber- 
dasarkan pengetahuan yang diperoleh dari lembaga pendidikan baik yang berbasis sekolah umum, sekolah agama maupun pesantren dan yang diperoleh dari pelatihan atau training-training organisasi yang diikutinya. Dari itu dapat kita ambil kesimpulan sementara bahwa, lembaga-lembaga pendidikan dan trainingtraining yang pernah diikuti mereka belum ada narasi-narasi yang mengarah kepada munculnya radikalisme atau terorisme. Bahkan sebaliknya mereka masih sangat kuat ingin menjaga kemurnian ajaran Islam dari sentuhan pemikiran dan tindakan radikal dan merusakkan seperti terorisme.

Kedua, di sisi lain sebagaimana terdapat dalam ajaran Islam sendiri bahwa tindakan tegas dan pada tingkat tertentu harus bertindak keras sampai pada tingkat perang telah dimiliki idenya oleh semua aktivis muda Aceh. Hal ini memang didapat sejalan dengan proses belajar-mengajar mereka baik di lembaga pendidikan maupun saat kegiatan training organisasinya. Walaupun masa penerapannya tetap harus sesuai dengan petunjuk agama. Karena itu tindakan keras dan tegas atas nama agama akan mungkin muncul jika situasi telah sampai seperti digariskan dalam agama. Misalnya jika ada misionaris yang dengan angkuh memaksa idenya melakukan sesuatu yang bertentangan dengan aturan yang telah digariskan oleh agama dan negara sedangkan pemerintah tidak melakukan apa-apa, akan mungkin muncul gerakan-gerakan radikal, bisa saja dalam bentuk merusak atau membakar. ${ }^{11}$

Ketiga, kalau tindakan radikal seperti digambarkan di atas kemudian mendapat perlawanan, apalagi kalau kemudian pemerintah membiarkan saja atau bahkan membela, maka akan sangat mungkin gerakan lebih keras lagi seperti tingkat teror akan muncul. Untuk munculnya suatu gerakan setingkat teroris di Aceh tidak sulit, tidak perlu mendatangkan instruktur pelatih dari Pulau Jawa atau dari Poso, karena di Aceh banyak mantan kombatan GAM yang telah sangat berpengalaman latihan di berbagai negara dan sangat berpengalaman dalam bidang perang dan teror. ${ }^{12}$ Apalagi kalau bertemu dua kekecewaan, pertama kekecewaan masyarakat kepada sikap angkuhnya tokoh-tokoh agama non-Muslim dan kekecewaan mantan kombatan GAM terhadap sikap

\footnotetext{
11 Salah satu diantara yang mempercepat dan memperkuat Gerakan Aceh Merdeka di awal gerakannya adalah karena adanya gerakan kristenisasi di Aceh yang dilakukan secara vulgar dan kemudian pemerintah tidak memperhatikan keluhan rakyat Aceh mengenai hal tersebut. Lihat: Nazaruddin Syamsuddin, Intergrasi Politik di Indonesia, (Jakarta: Gramedia, 1989), h. 82. 2013.

12 Hanif Sofyan, “Damai Aceh; Jangan Ada Dusta diantara Kita!" Serambi Indonesia, 13 Agustus
} 
pemerintah atau aparaturnya maka kumpulan dua kekecewaan tersebut akan menjadi suatu kekuatan besar dalam memproduksi gerakan teroris. Perlu juga dihayati bahwa mantan kombatan GAM juga semua Muslim bahkan beberapa diantara mereka memang alumni pesantren. Karena itu isu agama juga sangat mudah tersentuh bagi mereka. Demikian dengan ulama jika sudah terkait dengan isu agama maka ulama juga sulit dipisahkan dari gerakan-gerakan ini. Minimal mereka diam tanpa memberi komentar atau tanda setuju. Di Aceh ulama adalah merupakan sumber inspirasi dan sumber energi untuk kuat tidaknya suatu gerakan yang akan muncul. ${ }^{13}$

Ketika kita menelusuri lebih dalam akar terorisme kontemporer di kalangan pemuda Muslim di Indonesia, diantaranya adalah karena rakyat Indonesia memiliki pemuda-pemuda yang sudah memiliki pengalaman dalam berjihad melawan kafir yang diyakini telah berusaha merusak Islam dan umatnya seperti di Afghanistan. Awalnya mereka diundang untuk berjihad melawan Soviet yang ateis untuk membebaskan Afganistan dari penjajahan mereka. Tanpa disadari sesungguhnya dukungan dan termasuk latihan keahlian berperang dibantu oleh Amerika, bahkan mereka pernah mendapat pujian dan sanjungan dari Presiden Amerika, Ronald Reagan pada tahun 1986. Dan perang itu pun pada hakikatnya adalah kelanjutan dari perang dingin blok kapitalis dan komunis. Tetapi begitu cita-cita Amerika tercapai mereka ditinggalkan begitu saja padahal energi tempur mereka luar biasa. Kelebihan energi inilah yang mereka salurkan untuk mengobarkan terorisme dengan jubah jihad di berbagai tempat termasuk di Indonesia. $^{14}$

Jika paradigma itu diterapkan dalam kasus Aceh, Gerakan Aceh Merdeka baru saja berhenti berperang dengan RI pada tahun 2005. Dalam satu laporan ada 5000 tentara terlatih yang dimiliki oleh GAM ketika itu yang sekarang harus berdiam diri karena tidak ada lagi peperangan. Ketika diakhiri perang di antara

\footnotetext{
13Pada awal terjadinya konflik antara GAM dan RI di Aceh ulama berusaha berdiri di garis netral, tetapi setelah melihat perilaku aparatur pemerintah yang terus bersikap tidak adil pada rakyat ditambah lagi tindakan-tindakan yang melanggar agama akhirnya pada tahun 2000 ulama Aceh mendukung gerakan para pemuda Aceh untuk meminta referandum kepada pemerintah pusat dengan opsi terus bergabung atau berpisah dengan Indonesia. Lihat: laporan Penelitian Kamaruzzaman Bustamam Ahmad, dkk., "Gejala Separatisme dan Dukungan Ulama di Aceh", laporan penelitian, (Banda Aceh: Lembaga Studi Agama dan Masyarakat Aceh (LSAMA), 2013), h. 4-5.

${ }^{14}$ Ahmad Syafii Maarif, "Noor Huda Ismail dan Karyanya, Sebuah Pengantar", dalam Noor Huda Ismail, Temanku Teroris: Saat Dua Santri Ngruki Menempuh Jalan yang Berbeda, (Jakarta: Penerbit Hikmah, 2010), h. xi-xii.
} 
mereka ada yang masih berumur 20 tahun, tentu masih sangat energik. Seperti kenyataan sekarang sebagian mereka memang tidak memiliki kegiatan apa-apa karena tidak memiliki skill lain kecuali pernah memegang senjata. Karena itu jika satu waktu ada tawaran yang menggiurkan untuk menyalurkan energi yang terpendam itu mungkin saja akan sangat mudah diterimanya. Fenomena selama ini menunjukkan ada oknum yang memanfaatkan energi mereka untuk kepentingan politik atau kepentingan ekonomi. Maka, jika kemudian di Aceh akan muncul lagi sumber-sumber konflik seperti konflik ketidakadilan atau konflik agama, akan sangat mungkin kelompok yang berkepentingan akan menggunakan energi mereka. Seperti sudah disinggung sebelumnya kalau nanti terjadi konflik agama maka energi mantan kombatan GAM semakin membara, selain ingin menyalurkan keahliannya dalam bidang perang dan teror, mereka juga akan terbakar dengan semangat "jihadnya".

Ada suatu gejala lain yang perlu mendapatkan perhatian dari semua pihak demi menciptakan Indonesia yang aman dan damai. Penelitian dari Lembaga Studi Agama dan Masyarakat di Aceh menemukan bahwa ada kelompok radikalisme Aceh yang sedang menuntut ilmu di Timur Tengah, khususnya di Yaman. Pada era Perang Dingin proses pengiriman mujahidin yang kemudian diubah menjadi teroris dilakukan di Pakistan dengan lahan perjuangan di Afganistan. Sementara setelah kejatuhan beberapa kekuatan besar di Timur Tengah yaitu Saddam Husein, Osama bin Laden, dan Muammar Qadafi, proses Arab Spring telah menyebabkan pola gejala radikalisme di Timur Tengah dijadikan sebagai kekuatan untuk menghadang kekuatan pemerintah masing-masing.

Seperti dapat dibaca di media massa dalam dua tahun terakhir telah terjadi perang tanding di Yaman, di mana saat itu, terdapat banyak sekali santri dari Indonesia yang terlibat, tidak terkecuali dari Aceh. Mereka dilatih menggunakan persenjataan, disamping menimba ilmu pengetahuan. Saat itu, muncul dua istilah Santri Garuda dan non Garuda. Adapun model santri pertama adalah santri yang mengembangkan tradisi ahl al-sunnah wa 'l-jamā'ah. Sementara yang kedua adalah model santri yang boleh jadi akan menjalankan misi jihad seperti pada era Maktab Khidmat di Peshawar, Pakistan. Model santri yang kedua inilah yang dikhawatirkan, jika mereka kembali ke tanah air setelah mereka menimba ilmu di Yaman. ${ }^{15}$ Dapat dibayangkan jika pemerintah tidak dapat menciptakan situasi $72-73$

15Kamaruzzaman Bustamam-Ahmad, dkk, “Gejala Separatisme dan Dukungan Ulama di Aceh”, h. 
daerah seperti diharapkan oleh rakyatnya, apalagi kalau sudah menyangkut masalah agama, ketika dua kekuatan ini bersatu yaitu mantan kombatan GAM dan alumni Yaman, pasti konflik besar akan berkobar di Aceh yang mungkin salah satu strategi yang akan digunakan adalah strategi teroris.

\section{Kesimpulan}

Dari uraian yang telah diterakan di atas ada beberapa hal yang perlu digarisbawahi. Pertama, konsep perjuangan model terorisme tidak dapat diterima oleh aktivis muda di Kota Banda Aceh. Mereka telah memahami ajaran Islam yang relatif komprehensif dan proporsional. Namun cita-cita mereka agar tegaknya syariat Islam di Aceh adalah suatu keniscayaan. Kedua, penegakan syariat Islam di Aceh yang sudah dimulai sejak tahun 2000, belum berjalan mulus. Kendalanya ada yang terdapat pada Pemerintah Aceh sendiri, ada juga yang terdapat pada Pemerintah pusat, selain pada pribadi oknum-oknum tertentu. Ketiga, masih ada kemungkinan ada yang berusaha mengail di air keruh. Ketika Aceh belum begitu mulus situasi keamanannya mereka berusaha memperkeruh dengan berbagai kegiatan sempalan, apakah usaha pendangkalan akidah atau kristenisasi. Keempat, dengan berakhirnya konflik bersenjata antara GAM dengan Pemerintah pusat, sejumlah kombatan GAM kehilangan pekerjaan, dimana mereka memiliki skill dalam bidang perang dan terror serta rata-rata umur mereka masih sangat energik. Karena itu jika situasi kondisi Aceh tidak terus dibangun sehingga menyenangkan semua pihak sangat mungkin energi mereka akan dimanfaatkan oleh orang-orang yang memiliki kepentingan.

Kesimpulan kedua, ketiga dan keempat dapat digolongkan sebagai potensi munculnya konflik bahkan bisa sampai pada perang dan teror ketika tidak ada pengelolaan negara dengan baik sehingga memenuhi keinginan rakyat, baik tentang isu keadilan maupun isu agama. Apalagi kalau kemudian diketahui ada unsur-unsur dari luar yang masuk ke Aceh dan mengganggu akidah umat di Aceh, yang seratus persen Islam dan kemudian pemerintah tidak dapat bertindak tegas, maka konflik besar akan muncul bahkan bisa sampai pada tindakan brutal. Walaupun kesimpulan pertama telah menyenangkan hati karena aktivis muda Kota Banda Aceh sudah relatif memahami Islam yang rạ̣matan li 'l-âlamīn, tetapi masih ada kemungkinan juga bisa terjerumus kepada tindakan radikal ketika mereka menghadapi kemungkaran yang epidemis, apalagi kalau terus berkelanjutan.[w] 


\section{BIBLIOGRAFI}

Ahmad, Kamaruzzaman Bustamam, dkk, "Laporan Penelitian: Gejala Separatisme dan Dukungan Ulama di Aceh", Banda Aceh: Lembaga Studi Agama dan Masyarakat (LSAMA), 2013.

Amiruddin, Hasbi, Perjuangan Ulama Aceh di tengah Konflik, Yogyakarta: CENNINETS Press, 2004.

Amiruddin, Hasbi, "Ulama Aceh dalam Undang-Undang Republik Indonesia No 44 Tahun 1999, " makalah "Seminar Ketahanan Ulama dalam Menghadapi Dinamika Sosial Politik Aceh", LSAMA Banda Aceh, 14 April 2013.

Ba'asyir, Abu Bakar, Tadzkiroh: Nasehat \& Peringatan Karena Alloh Untuk Para Penguasa Negara Karunia Allah Indonesia Yang Berpenduduk Mayoritas Kaum Muslimin, t.t.p., t.th.

Ba'asyir, Abu Bakar, Tadzkiroh (Peringatan dan Nasehat Karena Alloh) Kepada: Ketua MPR/DPR dan Semua Anggotanya Yang Mengaku Muslim \& Aparat Thaghut N.K.RI di Bidang Hukum dan Pertahanan yang Mangaku Muslim, Jakarta: JAT MEDIA CENTER, 2012.

Hasan, Noorhaidi, dkk., Instrumen Penelitian Narasi dan Politik Identitas: Pola Penyebaran dan Penerimaan Radikalisme dan Terorisme di Indonesia, Jakarta BNPT, 2013.

Katoppo, Marienne, Teroris Serang Islam, Bandung: Pustaka Hidayah, 2000.

Ma'arif, Ahmad Syafi'i, "Noor Huda Ismail dan Karyanya, Sebuah Pengantar", dalam Noor Huda Ismail, Temanku Teroris: Saat Dua Santri Ngruki Menempuh Jalan yang Berbeda, Jakarta: Penerbit Hikmah, 2010.

Majelis Permusyawaratan Ulama Aceh, Fatwa MPU No. 02, Tahun 2010, Mengenai Terorisme.

Syamsuddin, Nazaruddin, Intergrasi Politik di Indonesia, Jakarta: Gramedia, 1989.

Tim Penyusun Kamus, Kamus Besar Bahasa Indonesia, Jakarta: Balai Pustaka, 1999.

\section{Media Massa:}

Bah, "Terpidana Teroris Kecewa Tidak Ditahan di Aceh, " Serambi Indonesia", 20 Desember 2011. 
Faqih, Mansyur, dkk., "Ketika Pemberantasan Terorisme Meresahkan', Republika, 11 Januari 2013.

Fitrat, Irfan dan Dyah Ratna Novia, "Polisi Curigai Keterlibatan Teroris", Republika, 19 Agustus, 2013.

Munajat, "Memahami Gerakan Terorisme: Mungkinkah Berakhir?" Republika, 10 Agustus 2009.

Sofyan, Hanif, "Damai Aceh; Jangan Ada Dusta diantara Kita!" Serambi Indonesia, 13 Agustus 2013. 